\title{
STUDI LITERATUR : HUBUNGAN VITAMIN E ASETAT PADA ROKOK ELEKTRIK DENGAN KEJADIAN EVALI (E-Cigarette, or Vaping, Product Use Associated Lung injury)
}

\author{
Putri Radhiah ${ }^{1}$ \\ ${ }^{1}$ Program Studi Pendidikan Dokter Fakultas Kedokteran Universitas Lampung
}

\begin{abstract}
Literature Review : The Correlation between Vitamin E Acetate in E-cigarette and EVALI (E-Cigarette, or Vaping, Product Use Associated Lung injury). Surveys indicate more than two over three smokers use e-cigarette as one of the methods for smoking cessation. In contrast with safe claim that has been brought up in the past, e-cigarette has been reported causing newly found disease, EVALI (E-Cigarette, or Vaping, Product Use Associated Lung injury). First case reported on August 2019 and reached the peak of outbreak on September 2019 in United State of America. As of January 21, 2020, 2,711 people have been confirmed as EVALI hospitalized-patients. Some chemical substances in e-cigarette are being accused as causative agent of EVALI, such as vitamin E acetate. There for this article provide newly researches review about the correlation between vitamin E acetate and EVALI. Based on review that has been done, vitamin E acetate found in most of BAL fluid's patients ( $>90 \%$ of EVALI patients that have been tested). Moreover, lipid-laden macrophages have been found in mice-exposed aerosol VEA. Lipid-laden macrophages are invariably findings in patients with EVALI. In conclusion, vitamin E acetate has correlation with EVALI.
\end{abstract}

Keywords : e-cigarette, EVALI, Vitamin E acetate

\begin{abstract}
Abstrak: Studi Literatur Hubungan Vitamin E Asetat pada Rokok Elektrik dengan Kejadian EVALI (E-Cigarette, or Vaping, Product Use Associated Lung injury). Survei menunjukkan lebih dari dua pertiga perokok menggunakan rokok elektrik sebagai salah satu cara berhenti merokok. Bertentangan dengan klaim aman yang dipasarkan ke publik, rokok elektrik baru-baru ini dilaporkan menimbulkan penyakit terbaru yaitu E-Cigarette, or Vaping, Product Use Associated Lung injury (EVALI). Kasus EVALI pertama kali dilaporkan pada Agustus 2019 dan mencapai puncak pada September 2019. Hingga 21 Januari 2020, tercatat 2.711 pasien terkonfirmasi menderita EVALI di Amerika Serikat. Beberapa zat kimia yang terkandung pada rokok elektrik dicurigai menyebabkan EVALI, salah satunya adalah vitamin $\mathrm{E}$ asetat. Artikel ini bertujuan mengkaji literatur-literatur terbaru mengenai hubungan vitamin E asetat terhadap kejadian EVALI. Berdasarkan hasil kajian, sebagian besar pasien EVALI (>90\% dari pasien EVALI yang diuji) terdeteksi adanya vitamin E asetat pada cairan bronchoalveolar lavage (BAL). Makrofag lipidladen juga terdeteksi pada tikus yang dipaparkan VEA aerosol, jenis makrofag yang selalu pada cairan BAL pasien EVALI. Berdasarkan beberapa bukti yang ditemukan, dapat disimpulkan bahwa vitamin $\mathrm{E}$ asetat memiliki hubungan yang erat dengan penyakit EVALI.
\end{abstract}

Kata Kunci : EVALI, rokok elektrik, Vitamin E asetat 


\section{PENDAHULUAN}

Menurut WHO (2015), terdapat lebih dari 1,1 milyar penduduk dunia merupakan perokok. Indonesia menempati peringkat kedua prevalensi perokok tembakau usia lebih dari sama dengan 15 tahun pada tahun 2016 di Asia Tenggara dengan persentase 39\% (WHO, 2018). Menurut Riskesdas (2018), prevalensi perokok di Indonesia dari tahun ke tahun mengalami peningkatan terutama pada usia remaja. Pada tahun 2013 tercatat 7,2\% remaja usia 10 sampai 18 tahun merokok (Riskesdas, 2013) kemudian meningkat menjadi $8,8 \%$ pada tahun 2016 (Sirkesnas, 2016) dan data terakhir menunjukkan prevalensi perokok usia 10 hingga 18 tahun mencapai 9,1\% (Riskesdas, 2018).

Seiring meningkatnya jumlah perokok di dunia, efek negatif rokok konvensional telah banyak dipublikasikan. Merokok menyebabkan lebih dari 480.000 kematian di Amerika Serikat; meningkatkan risiko terkena penyakit jantung koroner (PJK) dua hingga empat kali lipat, stroke dua hingga empat kali lipat, dan kanker paru 25 kali lipat daripada bukan perokok. Selain itu, bayi dari ibu yang merokok juga dapat lahir dengan resiko prematur, lahir mati, berat badan lahir rendah (BBLR), atau mengalami Sudden Infant Death Syndrome (SIDS) (CDC, 2020b). Efek-efek berbahaya tersebut menyebabkan sejumlah pengguna rokok konvensional mencari alternatif lain untuk menggantikan rokok konvensional.

Salah satu alternatif rokok konvensional adalah rokok elektrik atau smoking-proxy electronic inhaling systems (SEIS). Berdasarkan beberapa survei yang telah dilakukan (Etter, 2010; Dawkins, dkk, 2013), banyak pengguna rokok elektrik percaya bahwa rokok elektrik dapat membantu mereka berhenti merokok. Lebih dari dua per tiga perokok menggunakan rokok elektrik untuk berhenti merokok atau mengurangi gejala withdrawal. Kepopuleran rokok elektrik semakin meningkat karena diyakini memiliki kandungan nikotin yang lebih rendah dari rokok konvensional dan berbeda dengan rokok konvensional yang telah dilarang adanya tambahan zat perisa, rokok elektrik justru dipasarkan dengan lebih dari 7000 rasa (Bhalerao dkk, 2018). Rokok elektrik atau dapat disebut sebagai e-cigarette, vapes, ehookahs, atau Electronic Nicotine Delivery System (ENDS) merupakan alat yang memanaskan cairan sehingga terciptanya aerosol, biasanya mengandung perisa yang dilarutkan pada propilen glikol dan/atau gliserin (WHO, 2016).

Meski terdapat klaim bahwa rokok elektrik lebih baik dibandingkan rokok konvensional, terdapat beberapa penelitian yang mengemukakan efek negatif dari kandungan kimia pada rokok eletrik. Menurut Benowitz (2010), nikotin menyebabkan dependensi; propilen glikol bila dihirup jangka pendek (309 mg/m $\mathrm{m}^{3}$ dalam satu menit) dapat menyebabkan iritasi mata, tenggorokan dan jalan nafas (German Cancer Research Center, 2013); dan gliserin dapat menyebabkan pneumonia lipoid (Hosmer dkk, 2012). Selain itu, banyak pengguna rokok elektrik terutama remaja mengalami penyakit pada paru yang berkaitan dengan vaping dan sejumlah orang dilaporkan meninggal dunia dikarenakan komplikasi dari penyakit paru yang berkaitan dengan vaping.

EVALI (E-Cigarette, or Vaping, Product Use Associated Lung injury) dilaporkan terjadi karena penggunaan rokok elektrik. Hingga 21 Januari 2020, CDC melaporkan bahwa terdapat 60 kematian dan 2.711 pasien rawat inap kejadian dikarenakan EVALI (CDC, 2020a). Berdasarkan laporan terbaru CDC (Board dkk, 2020) hingga 14 Januari 2020, terdapat $82 \%$ pasien EVALI di seluruh negara menggunakan rokok elektrik yang mengandung tetrahydrocannabinol (THC) dan 57\% menggunakan rokok elektrik yang mengandung nikotin. Vitamin $\mathrm{E}$ asetat (pelarut THC), minyak MCT (medium chain trigycerides), minyak tumbuhan (long chain triglycerides), sulingan minyak bumi (termasuk minyak mineral), diluent terpenes, cannabinoids 
dan nikotin merupakan zat-zat kimia yang dicurigai berhubungan dengan kejadian EVALI (Blount dkk, 2020).

Kemungkinan penyebab EVALI masih diperdebatkan. Maka dari itu, tujuan artikel ini adalah mengkaji artikel-artikel penelitian terbaru yang meneliti mengenai hubungan vitamin $\mathrm{E}$ asetat terhadap munculnya EVALI. Dengan mengetahui penyebab terjadinya EVALI, dokter dapat meningkatkan ketepatan dalam menangani penyakit tersebut dan membantu meningkatkan pemahaman publik mengenai kandungan berbahaya yang ada pada rokok elektrik.

\section{METODE}

Metode yang digunakan dengan mengumpulkan dan mengkaji penelitian-penelitian terbaru yang membahas mengenai rokok elektrik, vitamin E asetat, dan EVALI yang sudah tertera pada sitasi dan daftar pustaka.

\section{HASIL DAN PEMBAHASAN}

Peningkatan kasus mengenai EVALI pertama kali dilaporkan oleh CDC pada Agustus 2019 dan angka kejadian mencapai puncak pada September 2019 (Board dkk, 2020). Hal ini memicu para peneliti untuk meneliti lebih dalam mengenai EVALI mulai dari etiologi hingga manajemen penyakit. $E$ Cigarette, or Vaping, Product Use Associated Lung injury (EVALI) merupakan penyakit yang terjadi akibat penggunaan rokok elektrik dan sejenisnya. Tetrahidrokanabinol (THC) dan vitamin $\mathrm{E}$ asetat (larutan pengental THC) dicurigai berkaitan erat munculnya penyakit EVALI di Amerika Serikat (Bount dkk, 2020; Bye dkk, 2019). CDC (2020a) melaporkan per 21 Januari 2020 terdapat 2711 pasien EVALI dan 60 pasien meninggal dunia.

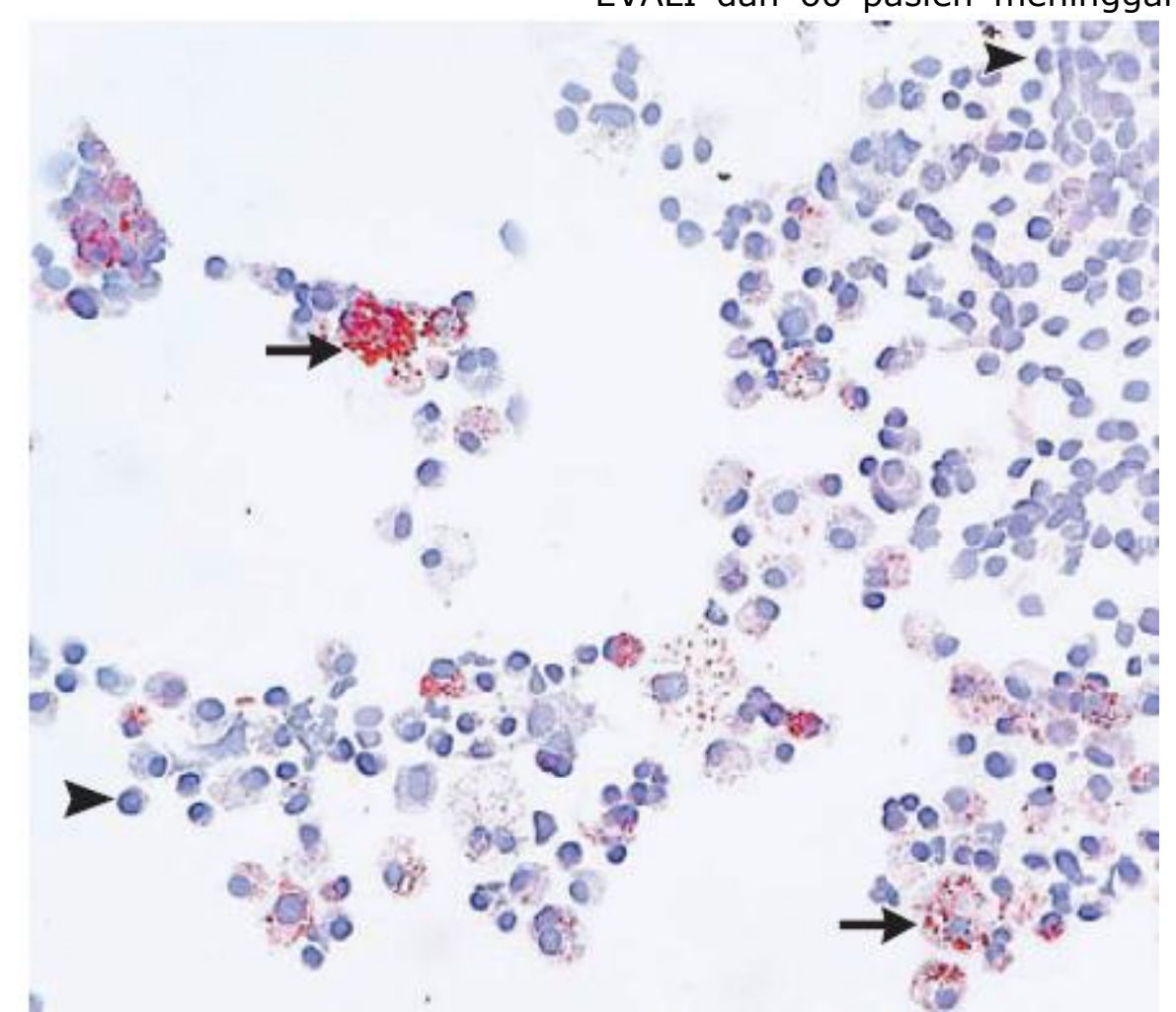

\section{Gambar 1. Sel dari cairan BAL Tikus yang Terpapar Vitamin E Asetat (Bhat et al, 2020)}

Vitamin E asetat (VEA) merupakan kandungan yang sering dimasukkan pada produk kosmetik seperti krim kulit dan suplemen makanan. Vitamin $E$ asetat akan dipecah oleh enzim menjadi vitamin $\mathrm{E}$ pada proses penyerapan di dalam tubuh (Borel dkk, 2013; Reboul, 2017). Walaupun vitamin E asetat lumrah terkandung pada kosmetik dan suplemen makanan, Kamal dkk (2012) 
menyatakan bahwa menghirup vitamin $\mathrm{E}$ asetat dalam bentuk aerosol dapat mengganggu fungsi paru (Kamal \& Raghunathan, 2012). Vitamin E asetat dilaporkan telah ditambahkan pada rokok elektrik yang mengandung THC untuk menurunkan biaya produksi; meningkatkan rasa dan aroma; serta meningkatkan kualitas dan penampilan produk (Burack dkk,2019).

Penelitian pertama yang menindaklanjuti kecurigaan mengenai vitamin E asetat sebagai kemungkinan penyebab EVALI dilakukan oleh Blount dkk (2020) yang mengemukakan bahwa terdapat vitamin $\mathrm{E}$ asetat pada cairan BAL 29 pasien dari 29 pasien EVALI (100\%). Uji cairan BAL dilakukan dengan metode isotope dilution mass spectrometry (IDMS) sehingga dapat mendeteksi toksin spesifik yang dicurigai berkaitan dengan terjadinya EVALI yaitu vitamin E asetat, minyak MCT (medium chain trigycerides), minyak tumbuhan (long chain triglycerides), sulingan minyak bumi (termasuk minyak mineral), diluent terpenes, cannabinoids dan nikotin. Toksin lain seperti minyak MCT, minyak tumbuhan, sulingan minyak bumi dan diluent terpenes berada dibawah kadar yang dapat dianalisis (rentang $\mathrm{ng} / \mathrm{mL}$ rendah). Selain itu, ditemukan bahwa pada 20 dari 28 sampel cairan BAL mengandung THC sedangkan 16 dari 26 pasien mengandung nikotin. Blount dkk (2020) menyimpulkan bahwa terdapat keterkaitan antara vitamin $\mathrm{E}$ asetat dan EVALI namun belum cukup bukti untuk memastikan bahwa vitamin $\mathrm{E}$ asetat sebagai penyebab utama terjadinya EVALI.

Bhat dkk (2020) melakukan penelitian terhadap 30 tikus (dibagi menjadi tiga kelompok masing-masing 10 tikus), grup pertama dipaparkan aeorosol dari vitamin $\mathrm{E}$ asetat, grup kedua dipaparkan propylene glycol dan vegetable glycerin (PG-VG) sedangkan grup ketiga dipaparkan udara (kontrol). Pada tikus yang dipaparkan vitamin $\mathrm{E}$ asetat diperkirakan akan menghirup 77,3 hingga $167,5 \mu \mathrm{g}$ vitamin $\mathrm{E}$ asetat tiap gram berat badan tikus, setara dengan pengguna rokok elektrik yang menghirup 0,52 hingga $1,13 \mathrm{~mL}$ produk vaping apapun dengan kandungan $88 \%$ vitamin $\mathrm{E}$ asetat. Dari hasil penelitian, terlihat bahwa vitamin $\mathrm{E}$ asetat efektif masuk ke dalam paru. Hal ini terlihat dari terdeteksinya $\geq 4 \times 10^{3} \mu \mathrm{g} / \mathrm{mL}$ vitamin $E$ asetat di cairan bronchoalveolar lavage (BAL) pada tikus grup satu $(p<0,001)$. Selain itu, tikus yang dipaparkan VEA mengalami peningkatan kadar albumin (penanda kerusakan epitel paru) yang signifikan pada cairan BAL daripada tikus yang terpapar PG-VG atau udara $(p<0,001)$, peningkatan jumlah leukosit (sel CD45+) $\quad(p<0,001)$, dan terlihat sejumlah makrofag lipid-laden pada selsel di cairan BAL yang biasanya selalu ditemukan pada pasien EVALI (Gambar 1). Tikus yang dipaparkan PG-VG terlihat lebih sedikit makrofag yang dapat terdeteksi. Terdapat makrofag alveolar dan melimpahnya lipid yang terwarnai dengan pewarnaan minyak red $O$ di jaringan paru pada tikus yang terpapar VEA (Gambar 2) sedangkan pada jaringan paru yang terpapar PGVG terdapat granula kecil yang terwarnai minyak red $O$ pada sitoplasma sel yang berjajar sepanjang alveoli. 


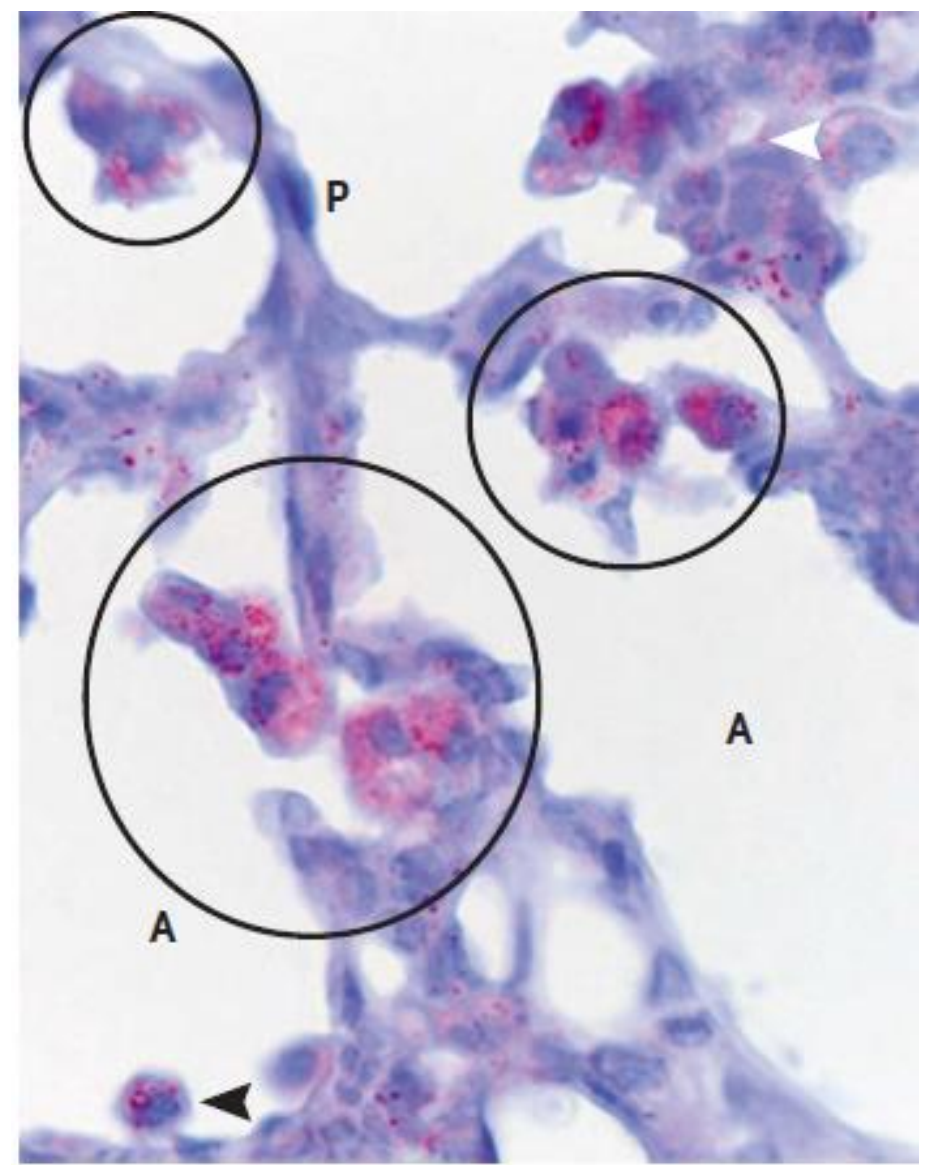

\section{Gambar 2. Jaringan Paru Tikus yang Terpapar Vitamin E Asetat (Bhat dkk, 2020)}

Penelitian lanjutan untuk membandingkan cairan BAL antara kelompok kontrol dan pasien EVALI dilakukan oleh Blount dkk (2020) kepada 51 pasien EVALI (25 pasien terkonfimasi (confirmed) EVALI dan 26 pasien mungkin (probable) EVALI yang diambil dari 16 negara bagian di Amerika Serikat) dan 99 partisipan sehat (37\% bukan perokok, 67\% perokok rokok elektrik, $76 \%$ perokok rokok konvensional). Penelitian dilakukan dengan mengambil sampel cairan BAL kemudian dilakukan pendeteksian toksin spesifik seperti vitamin $\mathrm{E}$ asetat, minyak tumbuhan, minyak MCT, minyak kelapa, sulingan minyak bumi, dan diluent terpene dengan metode IDMS. Hasil penelitian menunjukkan bahwa tidak ditemukannya vitamin $\mathrm{E}$ asetat di cairan BAL pada partisipan yang sehat. Pada 48 dari 51 pasien EVALI (94\%) terdeteksi adanya vitamin E asetat, satu pasien EVALI terdeteksi adanya minyak kelapa dan vitamin $\mathrm{E}$ asetat sedangkan satu pasien lain terdeteksi adanya limonene tanpa ditemukannya vitamin $\mathrm{E}$ asetat di cairan BAL. Terdapat 47 dari 50 (94\%) pasien terdeteksi adanya THC atau metabolitnya pada cairan BAL dan dikonfirmasi menggunakan produk mengandung THC dalam kurun waktu 90 hari. Selain itu, terdapat 37 dari 47 pasien yang terdeteksi adanya nikotin dan metabolitnya.

Hasil penelitian-penelitian diatas menunjukkan keterkaitan yang erat antara vitamin $\mathrm{E}$ asetat dan penyakit EVALI. Namun karena keterbatasan penelitian, vitamin $\mathrm{E}$ asetat belum dapat dipastikan sebagai penyebab utama penyakit EVALI. Penelitian yang dilakukan Bount dkk (2020) belum meneliti lebih lanjut mengenai komponen-komponen aerosol rokok elektrik selain vitamin E asetat sehingga belum diketahui ada tidaknya 
komponen-komponen yang bekerja secara sinergis atau soliter dalam memengaruhi munculnya penyakit EVALI. Sedangkan penelitian oleh Bhat dkk (2020) mengatakan bahwa keterbatasan penelitian mereka berupa adanya kemungkinan produk sampingan hasil degradasi termal pada vitamin $\mathrm{E}$ asetat saat pemanasan dan kemungkinan munculnya hasil yang mirip jika sampel dipaparkan dengan aerosol yang berasal dari pelarut lipofilik lain selain vitamin $\mathrm{E}$ asetat.

\section{SIMPULAN}

Berdasarkan kajian yang telah dilakukan terhadap beberapa penelitian mengenai vitamin $\mathrm{E}$ asetat pada rokok elektrik, dapat disimpulkan bahwa vitamin $E$ asetat memiliki hubungan yang erat dengan penyakit EVALI. Namun, penelitian lebih lanjut diperlukan untuk mengetahui lebih mendalam mengenai komponenkomponen rokok elektrik terutama vitamin $E$ asetat dan pengaruhnya terhadap EVALI sehingga dapat diketahui penyebab utama munculnya penyakit EVALI.

\section{DAFTAR PUSTAKA}

Benowitz, N.L. (2010). Nicotine addiction. N Engl J Med, 362, 2295-2303

Bhalerao, A., Cucullo, L., Kaisar, M. A., \& Sivandzade, F. (2018). Conventional and electronic cigarettes dysregulate the expression of iron transporters and detoxifying enzymes at the brain vascular endothelium: In vivo evidence of a gender-specific cellular response to chronic cigarette smoke exposure. Neuroscience letters, 682,1-9. https://doi.org/10.1016/j.neulet.2 018.05.045

Bhat, T. A., Blount, B. C., Bogner, P. N., Goniewicz, M. L., Kalathil, S. G., \& Thanavala, Y. M. (2020). An Animal Model of Inhaled Vitamin E Acetate and EVALI-like Lung
Injury. The New England journal of medicine, 382(12), 1175-1177. https://doi.org/10.1056/NEJMc200 0231

Blount, B. C., Braselton, M., Brosius, C. R., Caron, K. T., Corstvet, J., Cowan, E, dkk. (2020). Vitamin E Acetate in Bronchoalveolar-Lavage Fluid Associated with EVALI. The New England journal of medicine, 382(8), 697-705. https://doi.org/10.1056/NEJMoa19 16433

Board, A., Hartnett, K.P., Hallowell, B.D., Ko, J.Y., Krishnasamy, V.P., Salvatore, P.P., dkk. (2020). MMWR Update: Characteristics of a Nationwide Outbreak of Ecigarette, or Vaping, Product UseAssociated Lung Injury - United States, August 2019-January 2020, 69(3), 90-94

Borel, P., Crenon, I., Desmarchelier, C., Prévéraud, D.P., Rosilio, V., Samson-Kremser, C., dkk. (2013). The distribution and relative hydrolysis of tocopheryl acetate in the different matrices coexisting in the lumen of the small intestine during digestion could explain its low bioavailability. Molecular nutrition \& food research, 57(7), 1237-1245.

https://doi.org/10.1002/mnfr.201 200720

Burack, B., Cheng, C., Eisenberg, Z., Lam, V., Moy, D., \& Richard, J. (2019, October 2016). Contaminant analysis of illicit vs regulated market extracts. Retrieved from https://cannabis.anresco.com/anal ysis-of-illicit-vs-regulatedmarketextracts

Bye M., Cole C., Danila R., D'Heilly P., Hanson K., Holzbauer S., dkk. (2019). Characteristics of ecigarette, or vaping, products used by patients with associated lung 
injury and products seized by law enforcement-Minnesota, 2018 and 2019. MMWR Morb Mortal Wkly Rep, 68, 1096-1100.

CDC. (2020, January 28). States Update Number of Hospitalized EVALI Cases and EVALI Death. Retrieved from

https://www.cdc.gov/media/releas es/2020/s0128-evali-cases.html

CDC. (2020, April 28). Health effect of cigarette smoking. Retrieved from https://www.cdc.gov/tobacco/data _statistics/fact_sheets/health_effe cts/effects_cig_smoking/

Dawkins, L., Roberts, A., Soar, K., \& Turner, J. (2013). 'Vaping' profiles and preferences: an online survey of electronic cigarette users. Addiction (Abingdon, England), 108(6), 1115-1125. https://doi.org/10.1111/add.1215 0

Etter, J.F. (2010). Electronic cigarettes: a survey of users. BMC Public Health, 10, 231

German Cancer Research Center. (2013). Electronic cigarettes: an overview. retrieved from : https://www.dkfz.de/en/presse/do wnload/RS-Vol19-E-CigarettesEN.pdf

Hosmer, D., Markin, C., \& McCauley, L.(2012). An unexpected consequence of electronic cigarette use. Chest, 141(4), 1110-1113.

https://doi.org/10.1378/chest.111334Kamal, M. A., \& Raghunathan, V. A. (2012). Modulated phases of phospholipid bilayers induced by tocopherols. Biochimica et biophysica acta, 1818(11), 2486-
2493.

https://doi.org/10.1016/j.bbamem .2012.06.016

Lee, H. (2020). Medical Hypotheses Vitamin $\mathrm{E}$ acetate as linactant in the pathophysiology of EVALI. Medical Hypotheses, 144, 110182. https://doi.org/10.1016/j.mehy.20 20.110182

Reboul E. (2017). Vitamin E Bioavailability: Mechanisms of Intestinal Absorption in the Spotlight. Antioxidants (Basel, Switzerland), 6(4), 95. https://doi.org/10.3390/antiox604 0095

Riskesdas. (2013). Laporan Nasional Riset Kesehatan Dasar 2013. Jakarta: Badan Penelitian dan Pengembangan Kesehatan Kementerian Kesehatan RI

Riskesdas. (2018). Laporan Nasional Riset Kesehatan Dasar 2018. Jakarta: Badan Penelitian dan Pengembangan Kesehatan Kementerian Kesehatan RI

Sirkesnas. (2016). Survei Indikator Kesehatan Nasional 2016. Jakarta: Badan Penelitian dan Pengembangan Kesehatan Kementerian Kesehatan RI

WHO. (2015). Prevalence of tobacco smoking. Retrieved from https://www.who.int/gho/tobacco/ use/en/

WHO. (2018, March 23). Prevalence of tobacco smoking in 2016. Retrieved from https://apps.who.int/gho/data/nod e.sdg.3-a-viz?lang=en 